\title{
Family and Its Place in the Structure of Civil Relationships
}

\author{
Khurshed Nasirov* \\ Law Department, Russian-Tajik Slavonic University, M.Tursunzoda str., 30, Dushanbe, 734025, Tajikistan
}

\begin{abstract}
The author studies the place of the family in the structure of family relations. The correlation between civil law and family law in Soviet, Russian and Tajik legal science is considered. According to the author, the family is a social unit of society with the help of which people seek to solve demographic, economic and cultural issues. It is stated that the family is an alliance of persons created on the marriage, kinship, birth and adoption of children, as well as their upbringing. Accordingly, such alliance leads to the development of certain personal non-property and property rights and obligations based not only on mutual interests and concerns, but primarily on the related ties. In this regard, it seems logical that the specific nature of these rights and obligations requires the use of special tools for legal regulation; the content of legal relations arising on their basis is considered to be independent family relations.
\end{abstract}

\section{Introduction}

The issue of the family law as an independent branch of law, as well as its place in the common law system has always been controversial in legal science. Some scientists thought (some still do) that there were no grounds for separating family law into an independent branch. In their opinion, within the family and civil laws, the range of property and non-property (and, moreover, identical) relations is regulated on the basis of equality principles of subjects with the help of quite identical, dispositive and imperative methods. For these reasons, initially it was O.S. Ioffe and then M.A. Antokolskaya and A.P. Sergeev who proposed to consider the family law as a sub-branch of the civil law. In Tajikistan Sh. Menglieva is one of the supporters of this point of view.

In the opinion of supporters of another point of view family law has sufficient distinctive grounds to be separated into an independent branch. In their opinion such properties as non-transferability and inalienability of family rights, their personal gratuitous nature, inadmissibility of succession should become specific features necessary and sufficient to recognize the family law governing these relations. Individualization of subjects participating in these relations, their indispensability to others becomes very specific in the framework of family relations. Unlike civil relations, the family relations should be based on moral principles rather than on the property ones. The totality of social relations arising from the marriage, creation of a family, birth and upbringing of children should be the subject of the study of the family law. That is why the concept of the family is regarded on the instinctive level. Being regulated by the family law, all these social ties are conditionally called family relations.

\section{Results and Discussions}

The main subject of study relates to the recognition of relations connected with the family formation and its functioning. In other words, the basis for the presented point of view is predetermined by the key concept of the family.

\subsection{Language objectification of the word family}

In the well-known explanatory dictionaries and encyclopedias of the Russian language the following explanations of the word family are given:

1. A group of close relatives living together (Dictionary of the Russian Language).

2. A group of close relatives (husband, wife, parents, children, etc.) living together (Efremova Russian Explanatory Dictionary).

3. A group of people consisting of parents, children, grandchildren and close relatives living together (Ushakov Dictionary) [1].

4. A small group based on marriage or blood relationship, whose members are bound by the commonality of life, mutual assistance, moral and legal responsibilities. The formation of a stable union under the disintegration of a tribal system. The first historical form of monogamy was the patriarchal family (headed by the father, including his descendants with their wives and children, as well as domestic slaves). Industrialization destroys the bond between the family and domestic production, preserving only everyday life management as an economic function; most families consist of spouses and their children (a nuclear family). In modern society there are two contradictory tendencies

* Corresponding author: netlawyer@ list.ru 
one of them is the renewal of the family on the basis of industrial and cultural progress (transformation of the family into a moral and legal union of men and women) and the growth of family conflicts and a considerable number of divorces. Most marriages are based on personal choice of future spouses; family relationships are characterized by their equality (Encyclopedia Dictionary) [2].

In the explanatory dictionary of Tajik language, the lexeme oila (family) is defined as follows: honavoda (domestic), zana furzand (wife and children); hashu tabor (relatives); sohibi zanu farsand va hashu tabor budan (to have a wife, children and relatives). In modern Tajik, a family is understood as a group that unites a husband, wife and children broader than all relatives on the blood line.

Along with the word oila the lexeme khonavoda, which is originally Tajik, is widely used. "Farhangi zaboni tochiki" gives the following definition: honavoda - honadon (house), oila (family), akhli hona (family members), zanu farsand (wife and children) [3].

As can it be seen from the given interpretations, in the originally Tajik terms the family is closely connected with the house (the first part of the last two words of khona has the meaning 'home'). The concept of a house and a family are put together on purpose since the house in the traditional consciousness of the Tajik people is not only a building for living, but a house uniting people connected with family ties.

\subsection{Definition of family in jurisprudence}

So far, in the family law theory and in other legal sciences the family has been defined as a circle of persons associated with personal non-property and property rights and obligations arising from marriage, kinship, adoption and other forms of admission of children for upbringing, and recognized to help strengthen family relations. In fact, in the family law science family criteria are based on the following criteria: officially registered marriage or other relations confirmed by the acts of civil status; property and personal-non-property relations that have arisen on the basis of this marriage and family ties between spouses and relatives; mutual support and co-education of children and dependents.

It was V.I. Sinaisky who noted that this definition of the family is devoid of any certainty and clarity [4]. According to G.F. Shershenevich a family, being the main unit of the state organism is an alliance of persons connected by marriage and persons born or adopted during the marriage, and in this respect only part of its social relations can be regulated by law. Indeed, if we consider the family exclusively through the prism of property and personal-non-property rights and duties that individuals have had in connection with marriage, establishment of kinship and adoption, then social and moral issues of family life will be left outside family relationship.

Today, from a legal point of view, the concept of family still does not have a clear and unshakable content.
Despite the fact that in modern science of the family law, the family is already seen as a more social phenomenon, which is a complex set of natural biological, psychological, spiritual and material links, which can partially be accepted for legal regulation [6]. In this connection, the legal literature proposes that any legal definition of a family cannot have a clear and unshakable content; therefore, it is necessary to concentrate more on legal research of certain elements of this institution of law [7].

In Tajikistan, in determining the place and role of family law within the Tajik law system several attempts were made to define a more precise and narrower concept of the family, and to comprehend the individual elements of this institution of family law. In particular, it was suggested to identify the concept of family with the institution of marriage. If the relations governed by the family law arise on the basis of the family, marriage and kinship, why is it impossible to identify institutions of marriage and family? Moreover, even in the absence of a legislative definition of marriage and family these institutions are proposed to be considered through a twodimensional format: as a legal fact and as a legal relationship.

\subsection{Marriage as a legal fact}

As a legal fact marriage is considered as a kind of act of civil status that generates family relations, which is a voluntary union of a man and a woman registered in accordance with the procedure established by the law [8]. In turn, as a legal relationship, marriage is regarded as certain subjective rights and obligations of personal non-property and property nature arising from spouses and regulated by the law [9]. It seems that such definition and comparison of the institutions of the family and marriage, on the one hand, severely restricts the subjective composition of these relations only to a married couple, and on the other hand, also limits the content of family and marriage relations to the subjective rights and obligations of spouses of property and nonproperty nature; its limits are physiological, spiritual, and sometimes even moral principles. Perhaps that is why in the legal literature it is noted that both moral and spiritual principles of family life should be regulated not only by the family legislation, but also by standards of morality.

If to talk about the spiritual and physiological aspects of family life, then they do not have anything to do with the jurisprudence even though in many cases they become the principal conditions for marriage and a family as whole. However, aspects of moral principles in the family cannot be excluded from the legal regulation and should become part of family relations [10, 11]. After all, personal non-property relationships between family members, like those between spouses and between parents and children are largely dependent on nurturing and educational principles, which constitute the basis of moral behavior of participants within family relationships [12]. Accordingly, the rights and obligations of family members in the process of 
nurturing and education cannot be legally unresolved [13].

\subsection{Inconsistency in the identification of marriage and family concepts}

From a legal point of view the identification of the legal concepts of marriage and family seems to be incorrect. In our opinion, marriage in its legal meaning is more important legal fact the basis of which is a free and voluntary union/alliance of men and women aimed at the development of family relations, that is, the creation of a family. In this respect, the family should already be regarded as a relationship that resulted from a voluntary union/alliance between a man and a woman concluded in accordance with the law. Moreover, it should be noted that marriage is the most important legal fact that generates family rights and obligations, however, it is not the only one. For example, according to Articles 50 and 54 of the Family Code of the Republic of Tajikistan [14] (FL RT) when establishing the paternity for children born from unmarried persons the parents' rights and obligations are identical to those children who were born within marriage. In this case, family relations between children and their parents arise due to the establishment of the fact of paternity, and not on the marital relations of parents.

The lack of clear understanding of the family and marriage concept in the family law theory was reflected in the legislative process where no clear legislative definition was provided. Thus, even during the Soviet times the legislator attempted to define marriage as a joint cohabitation of a man and a woman, having common household, mutual material support and coeducation of children, which was expressed in the Article 12 of the Code of Marriage, Family and Guardianship of the Russian SFSR. In the legal literature it was immediately noted that the basis for this definition was the material and legal element when the fact of cohabitation and joint household expressed in the mutual material support and upbringing of children became sufficient to call such relations a family relation and to call the legal facts the marriage [15]. In essence the law recognized actual marital relations as valid as the registered ones.

However, later on the idea of the institute of "actual marriage" had to be dropped. Current legislation does not recognize any rights and obligations of a personal and property nature (for men and women) on the basis of actual marital relations. Thus, according to Article 10 of the Criminal Code of Tajikistan, the most important criterion of marriage, distinguishing it from other legal facts in the family law, is the fact of its state registration within civil status records.

Therefore, when studying the constitutional foundations in the part of preservation and strengthening of the family and family relations M.A. Makhmudov suggested focusing the attention on the definition of the concept of a family member [16]. According to the scientist, the concept of the family should be directly linked with the family members by whom we imply persons living in the same family, members of different families, former members of the family, having joint property and personal non-property rights resulting from marriage, kinship, adoption and other forms of placement of children for upbringing [17].

It is obvious that definition of a family member proposed by a scientist, on the one hand is rather vague since it makes it possible to consider many persons who are somehow living together and involved in the immediate upbringing process of children, but who do not have any property or personally non-property relationships as family members. On the other hand, this definition is lopsided as it is based on the birth of a child and his/her upbringing.

\subsection{Interpretation of the concept of family members}

It goes without saying that only individuals can be the members of a family; moreover, they can be both citizens of Tajikistan and foreign citizens, as well as persons without any citizenship. However, according to the current legislation, in order to be recognized as family members, citizens need to determine and establish the ally. According to the law, kinship is regarded as the blood relationship of citizens originating from one another. Depending on the kinship, the law determines the scope of subjective rights and obligations among members in the family relationships. Those family members who have direct relationship, when the birth of a direct ancestor is taken into account, the scope of property and non-property rights is much broader than that of the family members in the lateral relationship when the birth of a common ancestor is taken into account. Thus, the close relationship between a mother and a daughter, who are in the first degree of the kinship, results in more rights and obligations of mutual content compared to the lateral relationship between a nephew and an uncle who are in the third degree of the kinship.

However, today the Tajik legislation brings up the importance of legally confirmed kinship. So the genetic father who wished to use his rights and responsibilities in the upbringing of a child, despite the existing direct blood relationship, can exercise his rights and take part in his/her upbringing and education only after a legally established paternity procedure; without going through such procedure he cannot be considered even as a direct relative of a child. In turn, even if the blood relationship is legitimized, it is not always possible to recognize a genetic father as a member of the child's family. In particular, during the establishment of paternity for the person who is not married to a mother of the child, the latter can marry and create a family with another person where the child lives and where he/she is being brought up. It is unlikely that a person in favor of whom the paternity was established can be considered a member of the family. At the same time, the recognized father, not having the status of a family member of the child, cannot be deprived of the rights and obligations aimed at the upbringing of the child and, accordingly, must be 
recognized as a full participant of the family relations $[18,19]$.

In spite of everything mentioned above the importance of the family, as a socially significant unit, has lost its relevance in modern society. Young people prefer to live together without any official state registration. At the same time, when these unregistered people give a birth to the children their scope of rights and responsibilities with regard to the upbringing of their child should be no less than that of the parents of children in a registered marriage. Moreover, it seems that children born and raised by their parents who did not manage to legally formalize their marriage relationships have the same property and personal non-property rights and obligations as children under the care of officially married parents.

\section{Conclusions}

As a social unit of society, with the help of which people are trying to solve demographic, economic and cultural issues the family is considered as an alliance based on marriage, kinship, birth and adoption of children, as well as their upbringing. Accordingly, the creation of such alliance leads to the establishment of certain personal non-property and property rights and obligations that are based not only on the mutual interests and concerns, but primarily on the allies. In this regard, it seems logical that the specific nature of these rights and obligations involves the use of special tools and mechanisms for legal regulation; and the content of legal relations arising on their basis is considered to be independent family relations.

The author expresses his gratitude to the Russian-Tajik Slavonic University for providing financial support for the study in the framework of the University Development Program for 2018.

\section{References}

1. Family - the meaning of the word in the explanatory dictionaries of Ozhegov, Efremova, Ushakov Retrieved from: https://glosum.ru/\%D0\%97\%D0\%BD\%D0\%B0\%D1 $\% 87 \% \mathrm{D} 0 \% \mathrm{~B} 5 \% \mathrm{D} 0 \% \mathrm{BD} \% \mathrm{D} 0 \% \mathrm{~B} 8 \% \mathrm{D} 0 \% \mathrm{~B} 5-$ $\% \mathrm{D} 1 \% 81 \% \mathrm{D} 0 \% \mathrm{BB} \% \mathrm{D} 0 \% \mathrm{BE} \% \mathrm{D} 0 \% \mathrm{~B} 2 \% \mathrm{D} 0 \% \mathrm{~B} 0$ $\% \mathrm{D} 0 \% \mathrm{~A} 1 \% \mathrm{D} 0 \% \mathrm{~B} 5 \% \mathrm{D} 0 \% \mathrm{BC} \% \mathrm{D} 1 \% 8 \mathrm{C} \% \mathrm{D} 1 \% 8 \mathrm{~F}$

2. Family - the meaning of the word in the explanatory dictionary of the Encyclopedia Retrieved from: https://glosum.ru/the meaning of-word-Family-in-the encyclopedia

3. Explanatory dictionary of the Tajik language (1969)

4. V.I. Sinaiski, Russian Civil Law (2002)

5. G.F. Shershenevich. Textbook of Russian Civil Law (published in 1907), 406 (1995)

6. S.N. Tagaeva, The legal nature of family and legal responsibility, Bulletin of Perm University. Juridical sciences, 3 (9), 153 (2010)

7. V.A. Ryasentsev, Soviet Family Law, 10 (1982)

8. A.A. Levushkin, Family law: a tutorial, 39 (2011)
9. M. Mahmudzoda, Konstitutsiya zaminai Tashakkuli Nizomi hukuki milli (macmui makolayu maurozaho), 275-277 (2014)

10. V.A. Ojgensicht, Moral and Law, 135 (1987)

11. S.N. Tagaeva, The legal nature of family and legal responsibility, Bulletin of Perm University. Juridical sciences, 3 (9), 152 (2010)

12. S.N. Tagaeva, To the problem of compensation for moral harm in the family law, Bulletin of Perm University. Juridical sciences, 1 (15), 157 (2012)

13. M.Z. Rakhimov, Masuliyati padaru modar va shassoni onhoro andvazkunanda baroi taalimu tarkbayi farand, Legislation, 1, 39 (2012)

14. Ahbori Majlisi Oli of the Republic of Tajikistan, 22, 303 (1998); 4, 196 (2006); 3, 201 (2008); 7, 546 (2010); 3, 177 (2011); 12, 855 (2011); 3, 195 (2013); 11, 960 (2015); 3, 143 (2016); 11, 881 (2016); Law of the RT of February 24, 2017, No. 1395

15. P.V. Krashenninikova, Family law, 35 (2008)

16. Mahkam Mahmudzoda, Konstitutsiya zaminai Tashakkuli Nizomi hukuki milli (macmui makolayu maurozaho), 275 (2014)

17. Mahkam Mahmudzoda, Konstitutsiya zaminai Tashakkuli Nizomi hukuki milli (macmui makolayu maurozaho), 275 (2014)

18. M.A. Makhmudov, Legal means for the preservation and strengthening of the family in Tajikistan, 165 (1998)

19. S.N. Tagaeva, To the peculiarities of family responsibility, Proceedings of the Academy of Sciences of the Republic of Tajikistan. Series philosophy and law, 2, 153-158 (2010) 